\title{
Morning hypertension for stroke and cardiovascular: clinical pearls for primary care
}

\author{
Al Rasyid ${ }^{1 *}$ and Elvan Wiyarta ${ }^{2}$
}

\begin{abstract}
Hypertension is the world's leading cause of mortality and morbidity. One of the phenomena that commonly occur in hypertensive as well as normotensive patients, is morning hypertension. Blood pressure (BP) follows a diurnal rhythm, reaching its highest level during the morning hours and dropping to the lowest level at midnight. Transient increases in BP in morning hypertension plus persistent stressors within 24 hours are thought to increase target organ damage and trigger cardiovascular events. Therefore, ambulatory BP monitoring or morning home BP monitoring is recommended as a strong predictor of cardiovascular events. There are two types of morning hypertension according to its underlying mechanisms; the first one is called nocturnal hypertensive morning hypertension, and the other one is morning-surge hypertension. Numerous studies have proved that this phenomenon often leads to several acute cardiovascular events, such as stroke, coronary artery disease, and peripheral artery disease. To prevent these complications, cost-effective management is needed, especially for identifying accurate diagnostic tools, as well as creating specific regimens. Therefore, to achieve appropriate management of hypertension, including morning hypertension, long-acting antihypertensive drugs should be used, at full doses and in the form of combination therapy. The clinical usefulness of antihypertensive drugs with specific mechanisms for morning BP or split or timed dosing of longacting drugs in controlling morning BP remains under investigation. More studies are needed, especially looking for other clinical evidence of the benefits of lowering BP in the morning. Home BP monitoring is recommended as a good choice for BP measurements, especially in the primary care setting.
\end{abstract}

Keywords: Morning hypertension, cardiovascular events, primary care, awareness, prevention
${ }^{1}$ Department of Neurology, Cipto Mangunkusumo Hospital, Faculty of Medicine, Universitas Indonesia, Jakarta, Indonesia

${ }^{2}$ Medical Education Study Program Faculty of Medicine,

Universitas Indonesia

\section{*Correspondence:}

Al Rasyid, MD, PhD, Stroke Consultant Department of Neurology, Cipto Mangunkusumo Hospital, Faculty of Medicine, Universitas Indonesia, 10430

Jakarta, Indonesia

Tel: +6281218676230

Email: alrasyid50@yahoo.com

ORCID ID: 0000-0002-7568-8124

Date of first submission, August 17, 2021

Date of final revised submission, November 25, 2021

Date of acceptance, December 6, 2021

This open access article is distributed under a Creative Commons AttributionNon Commercial-Share Alike 4.0 International License

Cite this article as: Rasyid A, Wiyarta
E. Morning hypertension for stroke and
cardiovascular : clinical pearls for pri-
mary care. Univ Med 2021;40:270-8.
doi: $10.18051 /$ UnivMed.2021.v40.270-
278




\section{INTRODUCTION}

Hypertension remains the leading cause of cardiovascular morbidity and mortality, including stroke, coronary heart disease, heart failure, chronic kidney failure, and central and peripheral vascular disease. ${ }^{(1-3)}$ Blood pressure $(\mathrm{BP})$ values for diagnosis and therapy are taken from the average of two measurements, although there are diurnal variation factors that influence it. ${ }^{(4)}$ Blood pressure tends to decrease during sleep and rise again in the morning. ${ }^{(5)}$ This is evidenced by the results of 24-hour ambulatory BP monitoring (ABPM) ${ }^{(6,7)}$ Based on various epidemiological studies, it was found that the prevalence of acute cardiovascular manifestations that have the potential to cause death, such as myocardial infarction, stroke, or sudden cardiac death, peaks in the morning, usually within 4-6 hours after awakening. ${ }^{(8,9)}$ Transient increases in BP, known as morning BP surge (MBPS), in morning hypertension plus persistent stressors within 24 hours are thought to increase target organ damage and trigger these cardiovascular events. ${ }^{(10-12)}$ Therefore, BP monitoring using outof-clinic $\mathrm{ABPM}$ or morning home BP monitoring (HBPM), is recommended as a strong predictor of cardiovascular events. ${ }^{(13-15)}$ Through these methods, the phenomenon of the white-coat effect and masked hypertension can be eliminated, and the measurements are more reproducible than in clinical examinations. This review will discuss more about morning hypertension and the things you need to know in primary care. Morning hypertension is a problem that is often taken for granted, but this condition can be potentially fatal, especially if not diagnosed early. The primary care physician as the front line in health services has an important role in diagnosing morning hypertension.

\section{Morning hypertension and morning blood pressure surge}

Available studies use several different definitions of MBPS as seen in Figure 1. ${ }^{(10)}$ Assessment of MBPS is generally carried out with 24-hour ABPM. According to Kario ${ }^{(10)}$ there are two definitions in use, namely sleep-troughsurge which is the value of BP in the morning (2 hours after waking) minus the lowest BP value during sleep, and pre awakening surge which is the value of BP in the morning minus the value of BP 2 hours before waking up. In other studies, MBPS is referred to as a rising surge, which is the difference in the value of BP that increases in the morning minus BP in the supine position as measured $<30$ minutes earlier. ${ }^{(17)}$ In another study, the difference in BP between the morning and evening values is called the morning and evening (ME) difference. ${ }^{(2)}$ In the Jichi Medical SchoolAmbulatory Blood Pressure Monitoring study and the International Database on Ambulatory Blood Pressure Monitoring in Relation to Cardiovascular Outcomes, pathological morning BP increases were in the $10^{\text {th }}$ percentile class of these BP values. ${ }^{(10)}$ However, there is no official consensus on a definition of this phenomenon or a threshold for pathological elevation.

In contrast to MBPS, morning hypertension is a $\mathrm{BP}$ value of $135 / 85 \mathrm{mmHg}$ in the morning, either through ABPM or HBPM. In the Japanese Society of Hypertension 2014 guidelines for the management of hypertension, the term masked morning hypertension was introduced, which refers to a home morning BP of $\geq 135 / 85 \mathrm{mmHg}$, but with normal clinic BP $(<140 / 90 \mathrm{~mm} \mathrm{Hg}){ }^{(17)}$ Regardless of the mechanism, either pathophysiological or as a result of inadequate antihypertensive therapy, morning hypertension is associated with more frequently occurring significant cardiovascular events in the post-wake period. ${ }^{(14)}$ The prevalence of this phenomenon is quite high in the population of patients who have been diagnosed with hypertension, namely 15.9$43.6 \%{ }^{(18)}$ Cases of masked morning hypertension are still found at a high rate in the controlled hypertension population, which is $23.1-60.7 \%$. $^{(19)}$

Morning hypertension is classified into 2 types, namely nocturnal hypertensive morning hypertension and morning-surge hypertension. ${ }^{(20,21)}$ The first type includes nondippers (i.e. BP that does not decrease at night) 


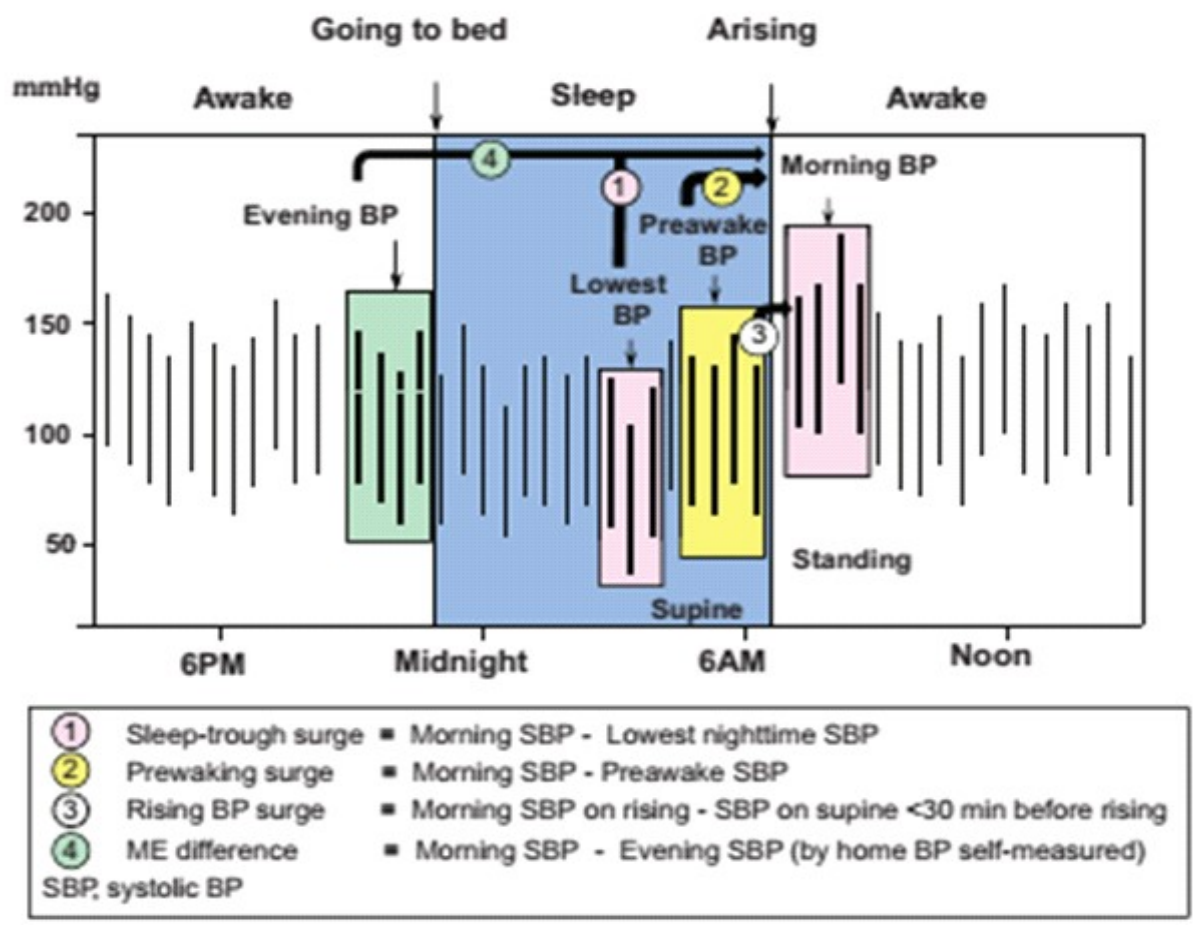

Figure 1. Definition of morning surge in $\mathrm{BP}{ }^{(10)}$

and risers (i.e. $\mathrm{BP}$ at night that is higher than during the day). ${ }^{(22)}$ Meanwhile, the second type is related to the phenomenon of morning surge, namely an increase in BP that starts 2 hours before waking up and increases after waking up. ${ }^{(22)}$

From the explanation above, it can be concluded that morning hypertension and MBPS are two different entities. A morning BP surge can still occur even without morning hypertension, for example in cases of excessively decreased nocturnal BP. On the other hand, morning hypertension can occur even though there is no significant MBPS, for example in the case of BP that remains high from night to morning.

\section{Mechanism of morning hypertension}

Morning hypertension is influenced by the sympathetic nervous system, the reninangiotensin system, and cortisol secretion. ${ }^{(23,24)}$ In normal individuals, this occurs physiologically, causing increased blood flow and shear stress. ${ }^{(25,26)}$ If there is vascular stenosis due to atherosclerosis, platelet aggregation and activation of plasminogen activator inhibitor 1 (PAI-1) occur. ${ }^{(27)}$ This mechanism is illustrated in Figure 2. ${ }^{(28)}$
Figure 2 explains the mechanism of damage to cardiovascular organs in this phenomenon. There are two genes that play a role, namely the central and peripheral clock genes. ${ }^{(28)}$ The central clock gene regulates variations in blood pressure in the morning, including sleep-wake cycles, body position, and physical activity. ${ }^{(28)}$ These things affect the body's physiology which is regulated by peripheral clock genes, namely the sympathetic nervous system and the renin-angiotensin system. ${ }^{(29)}$ Both of these factors contribute to an increase in MBPS in morning hypertension. ${ }^{(27,28)}$ Furthermore, MBPS also causes endothelial dysfunction and spasm, and platelet activation. ${ }^{(28)}$ Endothelial dysfunction further leads to plaque rupture in the blood vessels. When combined with increased activity of PAI-1 so that fibrinolytic activity decreases, it can put a person at high risk for these cardiovascular events. ${ }^{(27,28)}$ Several other studies have hypothesized that cardiovascular events in morning hypertension are associated with structural damage to large arteries, which in turn can lead to tearing of elastic fibers, hypertrophy and structural abnormalities of smooth muscle, and plaque rupture. ${ }^{(30-33)}$ This mechanism mainly occurs in atherosclerotic 


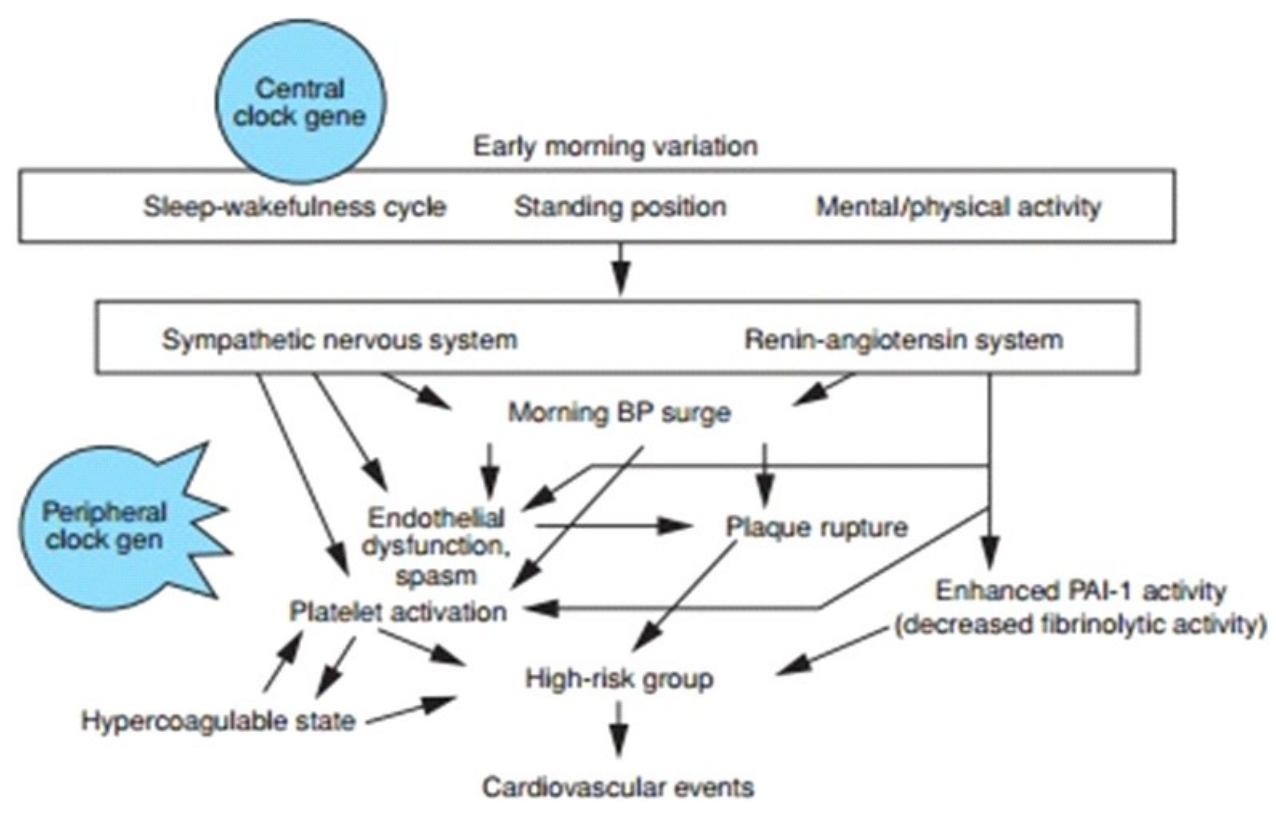

Figure 2. Organ damage mechanism in morning hypertension ${ }^{(28)}$

arteries, under conditions of high oxidative stress, and in the geriatric population with baroreflex dysfunction. ${ }^{(34)}$

\section{Cardiovascular risk of morning hypertension}

In previous studies, morning hypertension was considered a predictor of organ damage or cardiovascular outcome. ${ }^{(2)}$ In a study in Japan on a population of hypertensive patients, it was found that the group with morning and night $\mathrm{BP}$ differences in the highest quartile had a higher risk of developing concentric left ventricular hypertrophy than the group in the lowest quartile. ${ }^{(35)}$ In another study, the risk of stroke was found to be significantly higher in the morning hypertensive population than in the population with chronic hypertension. ${ }^{(36)}$ The Japan Morning Surge-Home Blood Pressure (J-HOP) study showed that morning home systolic BP (SBP) itself should be evaluated to ensure best stroke prediction in clinical practice, at least in Japan. ${ }^{(37)}$

A recent study from the International Database on Ambulatory Blood Pressure in Relation to Cardiovascular Outcome even shows that there is an increased risk of cardiovascular events by $30-40 \%$ in the population with MBPS. ${ }^{(38)}$ The MBPS group in the highest decile class was associated with the prognosis of stroke or brain infarction twice as high in later life..$^{(10)}$ Sleep-trough MBPS was significantly associated with a $25 \%$ increased risk of stroke. ${ }^{(10)}$ The study of the International Database on Ambulatory Blood Pressure in Relation to Cardiovascular Outcome concluded that the highest decile group in sleep trough $(\geq 37 \mathrm{mmHg}$ ) and pre awakening ( $\geq 28 \mathrm{mmHg}$ ) MBPS had a significantly higher risk of all-cause mortality and total cardiovascular events. ${ }^{(39)}$

\section{Recommendations for management of morning hypertension in primary care}

Despite the important clinical implications, specific guidelines for the management of morning hypertension have not been published to date, although several guidelines on hypertension have general recommendations regarding the management of morning hypertension, such as the British NICE ${ }^{(40)}$ and Canadian guidelines. ${ }^{(13)}$ Both guidelines recommend out-of-office BP measurements, such as the ABPM or HBPM, for diagnostic and therapeutic purposes. However, specific recommendations regarding morning hypertension have not been listed in either. The importance of measuring BP regularly, especially in the morning, is also supported by guidelines from several other countries, such as China, ${ }^{(11)}$ 
Table 1. Commonly used oral antihypertensive drugs from Cooper et al. ${ }^{(48)}$

\begin{tabular}{|c|c|c|c|c|}
\hline Class & Medication & Initial Dose & Dosing Interval & Maximal Dose \\
\hline \multirow{3}{*}{$\begin{array}{l}\text { Peripheral } \\
\text { antagonists }\end{array}$} & Prazosin & $5 \mu \mathrm{g} / \mathrm{kg}$ & 2 or 3 times per day & $0.4 \mathrm{mg} / \mathrm{kg}(15 \mathrm{mg})$ \\
\hline & Terazosin & $1 \mathrm{mg}$ & Daily & $20 \mathrm{mg}$ \\
\hline & Doxazosin & $1 \mathrm{mg}$ & Daily & $4 \mathrm{mg}$ \\
\hline \multirow{3}{*}{$\begin{array}{l}\text { Central } \\
\text { antagonists }\end{array}$} & Clonidine $\mathrm{e}^{\mathrm{a}}$ & $5-10 \mu \mathrm{g} / \mathrm{kg}$ & 2 or 3 times per day & $0.9 \mathrm{mg}$ \\
\hline & Methyldopa ${ }^{a, b}$ & $10 \mathrm{mg} / \mathrm{kg}$ & 2-4 times per day & $3 \mathrm{~g}(65 \mathrm{mg} / \mathrm{kg} / \mathrm{d})$ \\
\hline & Guanfacine $^{\mathrm{c}}$ & $1 \mathrm{mg}$ & Nightly & $2 \mathrm{mg}$ \\
\hline $\begin{array}{l}\text { Nonselective } \beta \\
\text { antagonists }\end{array}$ & Propranolol ${ }^{\mathrm{a}}$ & $1-2 \mathrm{mg} / \mathrm{kg}$ & 2 or 3 times per day & $4 \mathrm{mg} / \mathrm{kg}$ \\
\hline \multirow{4}{*}{$\begin{array}{l}\text { Selective } \beta 1 \\
\text { antagonists }\end{array}$} & Metoprolol a,b & & & \\
\hline & Immediate release & $1-2 \mathrm{mg} / \mathrm{kg}$ & 2 times per day & $6 \mathrm{mg} / \mathrm{kg}(200 \mathrm{mg} / \mathrm{d})$ \\
\hline & Extended release & $1 \mathrm{mg} / \mathrm{kg} / \mathrm{d}$ & Daily & $2 \mathrm{mg} / \mathrm{kg}(200 \mathrm{mg} / \mathrm{d})$ \\
\hline & Atenolol $^{\mathrm{a}}$ & $0.5-1 \mathrm{mg} / \mathrm{kg}$ & Daily, 2 times per day & $2 \mathrm{mg} / \mathrm{kg}(100 \mathrm{mg} / \mathrm{d})$ \\
\hline \multirow{6}{*}{$\begin{array}{l}\text { Mixed } \alpha / \beta \\
\text { antagonists }\end{array}$} & Labetalol $^{\mathrm{a}}$ & & & \\
\hline & Oral & $4 \mathrm{mg} / \mathrm{kg}$ & 2 times daily & $40 \mathrm{mg} / \mathrm{kg}$ \\
\hline & Intermittent bolus & $0.2-1 \mathrm{mg} / \mathrm{kg}$ & & $20 \mathrm{mg}$ \\
\hline & Carvedilol $^{\mathrm{a}}$ & & & \\
\hline & Immediate release & $6.25 \mathrm{mg}$ & 2 times daily & $50 \mathrm{mg}$ \\
\hline & Extended release & $20 \mathrm{mg}$ & Daily & $80 \mathrm{mg}$ \\
\hline \multirow{5}{*}{$\begin{array}{l}\text { Angiotensin- } \\
\text { converting } \\
\text { enzyme inhibitors }\end{array}$} & Captopril $^{\mathrm{a}}$ & $0.15-0.5 \mathrm{mg} / \mathrm{kg}$ & 2-4 times per day & $6 \mathrm{mg} / \mathrm{kg}$ \\
\hline & Enalapril $^{\mathrm{a}, \mathrm{b}}$ & $0.1-0.5 \mathrm{mg} / \mathrm{kg}$ & Daily, 2 times per day & $0.5 \mathrm{mg} / \mathrm{kg} /(40 \mathrm{mg}))$ \\
\hline & Fosinopril $^{\mathrm{b}}$ & $>50 \mathrm{~kg}, 5-10 \mathrm{mg}$ & Daily & $40 \mathrm{mg}$ \\
\hline & Lisinopril $^{\mathrm{a}, \mathrm{b}}$ & $0.07 \mathrm{mg} / \mathrm{kg}$ & Daily & $40 \mathrm{mg}$ \\
\hline & Benazepril ${ }^{a, b}$ & $0.1-0.6 \mathrm{mg} / \mathrm{kg}$ & Daily & $40 \mathrm{mg}$ \\
\hline \multirow{4}{*}{$\begin{array}{l}\text { Angiotensin } \\
\text { II receptor } \\
\text { blockers }\end{array}$} & Candesartan ${ }^{a, b}$ & $0.2 \mathrm{mg} / \mathrm{kg}$ & Daily, 2 times per day & 0.4 mg/kg (32 mg) \\
\hline & Valsartan ${ }^{\mathrm{a}, \mathrm{b}}$ & $1.3 \mathrm{mg} / \mathrm{kg}$ & Daily & $40 \mathrm{mg}$ \\
\hline & $\operatorname{Losartan}^{\mathrm{a}, \mathrm{b}}$ & $0.7 \mathrm{mg} / \mathrm{kg}$ & Daily & $100 \mathrm{mg}$ \\
\hline & $\begin{array}{l}\text { Olmesartan }{ }^{\mathrm{a}, \mathrm{d}} \\
20-35 \mathrm{~kg} \\
>35 \mathrm{~kg}\end{array}$ & $\begin{array}{l}10 \mathrm{mg} \\
20 \mathrm{mg}\end{array}$ & $\begin{array}{l}\text { Daily } \\
\text { Daily }\end{array}$ & $\begin{array}{l}20 \mathrm{mg} \\
40 \mathrm{mg}\end{array}$ \\
\hline \multirow{5}{*}{$\begin{array}{l}\text { Calcium channel } \\
\text { blockers }\end{array}$} & Amlodipine $\mathrm{a}, \mathrm{b}$ & $0.05-0.1 \mathrm{mg} / \mathrm{kg}$ & Daily, 2 times per day & $10 \mathrm{mg}$ \\
\hline & Felodipine & $2.5 \mathrm{mg}$ & Daily & $10 \mathrm{mg}$ \\
\hline & $\begin{array}{l}\text { Nifedipine } \\
\text { Immediate }\end{array}$ & $0.2-0.5 \mathrm{mg} / \mathrm{kg}$ & Every 4- & $10 \mathrm{mg}$ \\
\hline & Extended release & $0.2-0.5 \mathrm{mg} / \mathrm{kg}$ & Daily, 2 times per day & $3 \mathrm{mg} / \mathrm{kg}(120 \mathrm{mg})$ \\
\hline & $\begin{array}{l}\text { Isradipine }^{\mathrm{a}} \\
\text { Immediate release } \\
\text { Extended release }\end{array}$ & $\begin{array}{l}0.05-0.15 \mathrm{mg} / \mathrm{kg} \\
0.05-0.15 \mathrm{mg} / \mathrm{kg}\end{array}$ & $\begin{array}{l}\text { Every } 4-6 \text { h } \\
\text { Daily, } 2 \text { times per day }\end{array}$ & $\begin{array}{l}0.8 \mathrm{mg} / \mathrm{kg} / \mathrm{d}(20 \mathrm{mg}) \\
20 \mathrm{mg}\end{array}$ \\
\hline \multirow[t]{8}{*}{ Diuretics } & Chlorothiazide $^{\mathrm{a}, \mathrm{b}}$ & & & \\
\hline & Oral & $20 \mathrm{mg} / \mathrm{kg}$ & 2 times per day & $1 \mathrm{~g}$ \\
\hline & IV & $40 \mathrm{mg} / \mathrm{kg}$ & Daily, 2 times per day & $20 \mathrm{mg} / \mathrm{kg}$ \\
\hline & Hydrochlorothiazide ${ }^{b}$ & $1 \mathrm{mg} / \mathrm{kg}$ & Daily & $3 \mathrm{mg} / \mathrm{kg}(50 \mathrm{mg})$ \\
\hline & Chlorthalidone $^{\mathrm{a}}$ & $0.3 \mathrm{mg} / \mathrm{kg}$ & Daily & $2 \mathrm{mg} / \mathrm{kg}(50 \mathrm{mg})$ \\
\hline & Metolazone $^{\mathrm{a}}$ & $0.2-0.4 \mathrm{mg} / \mathrm{kg}$ & Daily, 2 times per day & $6 \mathrm{mg} / \mathrm{kg}$ \\
\hline & Furosemide $^{\mathrm{a}}$ & $1-2 \mathrm{mg} / \mathrm{kg}$ & Daily, 4 times per day & $100 \mathrm{mg}$ \\
\hline & Spironolactone $\mathrm{e}^{\mathrm{b}}$ & $1-3 \mathrm{mg} / \mathrm{kg}$ & 2-4 times per day & \\
\hline Vasodilators & $\begin{array}{l}\text { Hydralazine, } \\
\text { Oral }\end{array}$ & $0.7-1 \mathrm{mg} / \mathrm{kg}$ & 2-4 times per day & $25 \mathrm{mg}(200 \mathrm{mg} / \mathrm{d})$ \\
\hline
\end{tabular}

Note: ${ }^{a}$ Extemporaneously prepared infusion; ${ }^{\mathrm{b}}$ Approved by the US Food and Drug Administration (FDA) for patients $>6$ years old; ${ }^{\mathrm{c}} \mathrm{FDA}$ approved for patients $>12$ years old; ${ }^{\mathrm{d}} \mathrm{FDA}$ approved for patients $>1$ year old 
Korea ${ }^{(41)}$ and Taiwan, ${ }^{(42)}$ although they do not emphasize strict monitoring through ABPM and HBPM. The 2013 European Society of Hypertension guidelines, ${ }^{(43)}$ the 2014 guideline of the US Eight Joint National Committee (JNC8) ${ }^{(44)}$ and the 2020 guidelines of the International Society of Hypertension ${ }^{(45)}$ have not discussed this phenomenon.

The selection of the right drug in the management of morning hypertension raises a question mark among clinicians. In one study, long-acting antihypertensive drugs have the advantage of controlling the blood pressure for 24 hours. ${ }^{(46)}$ In another study, BP reductions were greater in the group receiving long-acting drugs, such as amlodipine and telmisartan. ${ }^{(47)}$ In addition, morning BP control was also better when antihypertensive drugs were given at full/ maximum doses compared to low doses, either in the form of monotherapy or combination therapy. ${ }^{(19)}$ The commonly used oral antihypertensive drugs can be seen in Table 1 which is taken from Cooper et al. ${ }^{(48)}$

Several studies have also compared the effect of antihypertensives given alone (monotherapy) or in combination on 24-hour BP control. Combination therapy of an angiotensinreceptor blocker (ARB) or angiotensinconverting enzyme inhibitor (ACEI) with a calcium-channel blocker (CCB) or diuretic can improve BP control within 24 hours. ${ }^{(19)}$ In a Japanese study, the combination of losartan and hydrochlorothiazide was able to significantly improve blood pressure control compared to high-dose losartan. ${ }^{(50)}$ Another study using a combination of ARB-CCB and ARB-ACEI showed similar results. ${ }^{(50)}$ In several other studies, the increase in morning blood pressure is associated with activation of the sympathetic nervous system and the renin-angiotensin system, therefore several hypotheses suggest the use of drugs that act specifically on this pathway. ${ }^{(51,52)}$ However, there have been no studies comparing the potential of each of the antihypertensive drugs separately to lower blood pressure in the morning.
Although clinical evidence of the effect of morning hypertension is abundant, studies on the relationship of morning blood pressure control for preventing cardiovascular events have not been widely carried out. The Anglo-Scandinavian Cardiac Outcomes Trial compared hypertensive patients receiving amlodipine and atenolol. As predicted, the decrease in blood pressure in the amlodipine group was greater at the time of measurement in the clinic and in the subject's home at night. ${ }^{(53)}$ After analysis, the hazard ratio for cardiovascular events in both groups was 0.74 (increased to 0.81 after adjusting for clinical systolic blood pressure measurements, and 0.85 after adjusting for night-time systolic blood pressure measurements). ${ }^{(53)}$ These results suggest that the long-acting effects of amlodipine may be beneficial to cardiovascular outcomes.

\section{CONCLUSION}

Morning hypertension is one of the important factors for various cardiovascular events that often occur in post-wake times. This is important for clinicians to know for the management of hypertension and the prevention of cardiovascular complications. Uncontrolled BP in the morning is a sign that the antihypertensive regimen given is not appropriate, either due to inadequate duration of action, inadequate dosage, or not using combination therapy. Therefore, to achieve appropriate management of hypertension, including morning hypertension, long-acting antihypertensive drugs should be used, at full doses and in the form of combination therapy. More studies are needed, especially looking for other clinical evidence of the benefits of lowering BP in the morning, compared to other times, on cardiovascular outcomes. More research is also needed to find the most accurate blood pressure monitoring method in detecting the morning blood pressure surge, as well as its specific therapy.

\section{CONFLICT OF INTEREST}

The authors declare no conflict of interest. 


\section{FUNDING}

No funding to declare.

\section{CONTRIBUTORS}

AR contributed to writing the manuscript. EW contributed to revising the manuscript. All authors have read and approved the final manuscript.

\section{REFERENCES}

1. Bilo G, Grillo A, Guida V, Parati G. Morning blood pressure surge: pathophysiology, clinical relevance and therapeutic aspects. Integr Blood Press Control 2018;11:47-56. doi: 10.2147/ IBPC.S130277.

2. Oh J, Lee CJ, Kim IC, et al. Association of morning hypertension subtype with vascular target organ damage and ventral hemodynamics. J Am Heart Assoc 2017;6:e005424. doi: 10.1161/JAHA. 116.005424 .

3. Wang JG, Kario K, Chen CH, et al. Management of morning hypertension: a consensus statement of an Asian expert panel. J Clin Hypertens (Greenwich) 2018;20:39-44. doi: 10.1111/jch.13140.

4. Oparil S, Acelajado MC, Bakris GL, et al. Hypertension. Nat Rev Dis Primers 2018;4:18014. doi: 10.1038/nrdp.2018.14.

5. NCD Risk Factor Collaboration (NCD-RisC). Worldwide trends in blood pressure from 1975 to 2015: a pooled analysis of 1479 population-based measurement studies with $19 \cdot 1$ million participants. Lancet 2017;389:37-55. DOI: https:// doi.org/10.1016/S0140-6736(16)31919-5.

6. Pena-Hernandez C, Nugent K, Tuncel M. Twentyfour-hour ambulatory blood pressure monitoring. J Prim Care Community Health 2020;11: 2150132720940519. doi: 10.1177/21501327209 40519.

7. Turner JR, Viera AJ, Shimbo D. Ambulatory blood pressure monitoring in clinical practice: a review. Am J Med 2015;128:14-20. doi: 10.1016/j.amjmed. 2014.07.021.

8. Katritsis DG, Gersh BJ, Camm AJ. A clinical perspective on sudden cardiac death. Arrhythm Electrophysiol Rev 2016;5:177-82. doi: 10.15420/ aer.2016:11:2

9. Marijon E, Uy-Evanado A, Dumas F, et al. Warning symptoms are associated with survival from sudden cardiac arrest. Ann Intern Med 2016; 164:23-9. doi: 10.7326/M14-2342.
10. Kario K. Morning surge in blood pressure and cardiovascular risk: evidence and perspectives. Hypertension 2010;56:765-73. https://doi.org/ 10.1161/HYPERTENSIONAHA.110.157149.

11. Sogunuru GP, Kario K, Shin J, et al. Morning surge in blood pressure and blood pressure variability in Asia: evidence and statement from the HOPE Asia Network. J Clin Hypertens (Greenwich) 2019;21:324-34. doi: 10.1111/jch.13451.

12. Booth JN, Jaeger BC, Huang L, et al. Morning blood pressure surge and cardiovascular disease events and all-cause mortality in Blacks: the Jackson heart study. Hypertension 2020;75:83543. https://doi.org/10.1161/HYPERTENSION AHA.119.14233

13. Houle SKD, Padwal R, Poirier L, Tsuyuki RT. The 2015 Canadian Hypertension Education Program (CHEP) guidelines for pharmacists: an update. Can Pharm J (Ott) 2015;148:180-6. doi: 10.1177/ 1715163515586847.

14. Kario K, Saito I, Kushiro T, et al. Morning home blood pressure is a strong predictor of coronary artery disease: the HONEST study. J Am Coll Cardiol 2016;67:1519-27. doi: 10.1016/j.jacc.2016. 01.037.

15. Kario K. Home blood pressure monitoring: current status and new developments. Am J Hypertens 2021;34:783-94. https://doi.org/10.1093/ajh/ hpab017.

16. Kim HJ, Shin YU, Lee Y, et al. Increasing incidence of macular edema in excessive morning blood pressure surge in patients with retinal vein occlusion. Sci Rep 2020;10:4420. https://doi.org/ 10.1038/s41598-020-61386-4.

17. Shimamoto K, Ando K, Fujita T, et al. The Japanese Society of Hypertension Guidelines for the management of hypertension (JSH 2014). Hypertens Res 2014;37:253-390. doi: 10.1038/ hr.2014.20.

18. Mills KT, Bundy JD, Kelly TN, et al. Global disparities of hypertension prevalence and control: a systematic analysis of population-based studies from 90 countries. Circulation 2016; 134:441-50. doi: 10.1161/CIRCULATIONAHA. 115.018912 .

19. Wang JG, Kario K, Park JB, Chen CH. Morning blood pressure monitoring in the management of hypertension. J Hypertens 2017;35:1554-63. doi: 10.1097/НJH.0000000000001379.

20. Sheppard JP, Hodgkinson J, Riley R, Martin U, Bayliss S, McManus RJ. Prognostic significance of the morning blood pressure surge in clinical practice: a systematic review. Am J Hypertens 2015;28:30-41. doi: 10.1093/ajh/hpu104. 
21. Bowles NP, Thosar SS, Herzig MX, Shea SA. Chronotherapy for hypertension. Curr Hypertens Rep 2018;20:97. doi: 10.1007/s11906-018-0897-4.

22. Hoshide S, Kario K. Early morning hypertension/ morning blood pressure surge. Nihon Rinsho 2014;72:1395-9.

23. Zhang $\mathrm{P}$, Jin MY, Song XY, Wang Z, Jiang YH, Yang $\mathrm{CH}$. Comparison of the antihypertensive efficacy of morning and bedtime dosing on reducing morning blood pressure surge: a protocol for systemic review and meta-analysis. Medicine (Baltimore) 2021;100:e24127. DOI: 10.1097/MD.0000000000024127.

24. Liu K, Xu Y, Gong S, et al. The disadvantage of morning blood pressure management in hypertensive patients. Medicine (Baltimore) 2020; 99:e19278. doi: 10.1097/MD.0000000000019278.

25. Aslanger E, Sezer M, Umman S. High blood pressure: an obscuring misnomer? Anatol J Cardiol 2016;16:713-9. doi: 10.14744/AnatolJ Cardiol.2016.7054.

26. GrilloA, Salvi L, Coruzzi P, Salvi P, Parati G. Sodium intake and hypertension. Nutrients 2019;11:1970. doi: 10.3390/nu11091970.

27. Kaur R, Kaur M, Singh J. Endothelial dysfunction and platelet hyperactivity in type 2 diabetes mellitus: molecular insights and therapeutic strategies. Cardiovasc Diabetol 2018;17:121. https://doi.org/10.1186/s12933-018-0763-3.

28. Kario K, Shimada K, Pickering TG. Clinical implication of morning blood pressure surge in hypertension. J Cardiovasc Pharmacol 2003;42 Suppl 1:S87-91. DOI: 10.1097/00005344200312001-00019.

29. Ames MK, Atkins CE, Pitt B. The reninangiotensin-aldosterone system and its suppression. J Vet Intern Med 2019;33:363-82. doi: 10.1111/jvim. 15454 .

30. Shimizu K, Takahashi M, Sato S, et al. Rapid rise of cardio-ankle vascular index may be a trigger of cerebro-cardiovascular events: proposal of smooth muscle cell contraction theory for plaque rupture. Vasc Health Risk Manag 2021;17:37-47. DOI https://doi.org/10.2147/VHRM.S290841.

31. Bonarjee VVS. Arterial stiffness: a prognostic marker in coronary heart disease. Available methods and clinical application. Front Cardiovasc Med 2018;5:64. doi: 10.3389/fcvm. 2018.00064.

32. Milutinović A, Šuput D, Zorc-Pleskovič R. Pathogenesis of atherosclerosis in the tunica intima, media, and adventitia of coronary arteries: an updated review. Bosn J Basic Med Sci 2020;20:21-30. doi: 10.17305/bjbms.2019.4320.
33. Espinosa MG, Staiculescu MC, Kim J, Marin E, Wagenseil JE. Elastic fibers and large artery mechanics in animal models of development and disease. J Biomech Eng 2018;140:0208031-3. doi: 10.1115/1.4038704.

34. Climie RE, van Sloten TT, Bruno RM, et al. Macrovasculature and microvasculature at the crossroads between type 2 diabetes mellitus and hypertension. Hypertension 2019;73:1138-49. https://doi.org/10.1161/HYPERTENSIONAHA. 118.11769 .

35. Kwon A, Ihm SH, Park CS. Morning blood pressure surge in the early stage of hypertensive patients impacts three-dimensional left ventricular speckle tracking echocardiography. Clin Hypertens 2021;27: 16. doi: 10.1186/s40885-02100173-3.

36. Gaciong Z, Siński M, Lewandowski J. Blood pressure control and primary prevention of stroke: summary of the recent clinical trial data and metaanalyses. Curr Hypertens Rep 2013;15:559-74. doi: 10.1007/s11906-013-0401-0.

37. Hoshide S, Yano Y, Haimoto H, et al. Morning and evening home blood pressure and risks of incident stroke and coronary artery disease in the Japanese general practice population. Hypertension 2016;68:54-61. https://doi.org/ 10.1161/HYPERTENSIONAHA.116.07201.

38. Boggia J, Thijs L, Hansen TW, et al. Ambulatory blood pressure monitoring in 9357 subjects from 11 populations highlights missed opportunities for cardiovascular prevention in women. Hypertension 2011;57:397-405. doi: 10.1161/ HYPERTENSIONAHA.110.156828.

39. Hermida RC, Ayala DE, Mojón A, Fernández JR. Sleep-time ambulatory BP is an independent prognostic marker of CKD. J Am Soc Nephrol 2017;28:2802-11. doi: 10.1681/ASN.2016111186.

40. Boffa RJ, Constanti M, Floyd CN, Wierzbicki AS. Hypertension in adults: summary of updated NICE guidance. BMJ 2019;367:15310. doi: 10.1136/ bmj.15310.

41. Lee HY, Shin J. Kim GH, et al. 2018 Korean Society of Hypertension Guidelines for the management of hypertension: part II-diagnosis and treatment of hypertension. Clinical Hypertension 2019; 25:20. https://doi.org/10.1186/s40885-019-0124-x.

42. Chiang CE, Wang TD, Ueng KC, et al. 2015 guidelines of the Taiwan Society of Cardiology and the Taiwan Hypertension Society for the management of hypertension. J Chin Med Assoc 2015;78:1-47. doi: 10.1016/j.jcma.2014.11.005.

43. Mancia G, Fagard R, Narkiewicz K,et al. 2013 ESH/ ESC guidelines for the management of arterial 
hypertension: the task force for the management of arterial hypertension of the European Society of Hypertension (ESH) and of the European Society of Cardiology (ESC). Eur Heart J 2013;34: 2159-219. https://doi.org/10.1093/eurheartj/ eht151.

44. James PA, Oparil S, Carter BL, etal. 2014 Evidencebased guideline for the management of high blood pressure in adults report from the panel members appointed to the eighth joint national committee (JNC 8). JAMA 2014;311:507. doi:10.1001/jama. 2013.284427.

45. Unger T, Borghi C, Charchar F, et al. 2020 International Society of Hypertension Global Hypertension Practice Guidelines. Hypertension 2020;75:1334-57. https://doi.org/10.1161/ HYPERTENSIONAHA.120.15026.

46. Fares H, Di Nicolantonio JJ, O'Keefe JH, Lavie CJ. Amlodipine in hypertension: a first-line agent with efficacy for improving blood pressure and patient outcomes. Open Heart 2016;3:e000473. doi: 10.1136/openhrt-2016-000473.

47. Wright JM, Musini VM, Gill R. First-line drugs for hypertension. Cochrane Database Syst Rev 2018;4:Cd001841. doi: 10.1002/14651858. CD001841.pub3.

48. Cooper E, Flores S, Basu R. Hypertension evaluation and management. In : Stockwell JA, Kutko MC, editor, Comprehensive critical care: pediatric; 2nd ed. Mount Prospect, Illinois, USA: Society of Critical Care Medicine;2016.p. 951-61.
49. Hanayama Y, Uchida HA, Nakamura Y, Makino H. Losartan/hydrochlorothiazide combination therapy surpasses high-dose angiotensin receptor blocker in the reduction of morning home blood pressure in patients with morning hypertension. Acta Med Okayama 2012;66:44959. doi: 10.18926/AMO/49041.

50. Omboni S, Volpe M. Angiotensin receptor blockers versus angiotensin converting enzyme inhibitors for the treatment of arterial hypertension and the role of olmesartan. Adv Ther 2019;36:27897. doi: 10.1007/s12325-018-0859-x.

51. Miller AJ, Arnold AC. The renin-angiotensin system in cardiovascular autonomic control: recent developments and clinical implications. Clin Auton Res 2019;29:231-43. doi: 10.1007/ s10286-018-0572-5.

52. Vian J, Pereira C, Chavarria V, et al. The reninangiotensin system: a possible new target for depression. BMC Med 2017;15:144. doi: 10.1186/ s12916-017-0916-3.

53. Gupta A, Mackay J, Whitehouse A, et al. Longterm mortality after blood pressure-lowering and lipid-lowering treatment in patients with hypertension in the Anglo-Scandinavian Cardiac Outcomes Trial (ASCOT) Legacy study: 16-year follow-up results of a randomised factorial trial. Lancet 2018;392:1127-37. doi: 10.1016/S01406736(18)31776-8. 